\title{
A Clinical Perspective in Evolutionary Medicine: What We Wish We Had Learned in Medical School
}

\author{
Joe Alcock • Mark D. Schwartz
}

Published online: 5 November 2011

(C) Springer Science+Business Media, LLC (outside the USA) 2011

\begin{abstract}
Medical students have much to gain by understanding how evolutionary principles affect human health and disease. Many theoretical and experimental studies have applied lessons from evolutionary biology to issues of critical importance to medical science. A firm grasp of evolution and natural selection is required to understand why the human body remains vulnerable to many diseases. Although we often integrate evolutionary concepts when we teach medical students and residents, the vast majority of medical students never receive any instruction on evolution. As a result, many trainees lack the tools to understand key advances and miss valuable opportunities for education and research. Here, we outline some of the evolutionary principles that we wished we had learned during our medical training.
\end{abstract}

Keywords Medical education · Evolution · Natural selection · Phylogeny · Virulence · Host defenses ·

Tradeoffs $\cdot$ Ultimate causation

\section{J. Alcock $(\bowtie)$}

Department of Emergency Medicine,

University of New Mexico,

Albuquerque, NM 87131, USA

e-mail: joalcock@salud.unm.edu

\section{D. Schwartz}

Department of Medicine,

New York University School of Medicine,

New York, NY 10010, USA

\section{J. Alcock}

Emergency Medicine Service,

New Mexico VA Health Care System,

1501 San Pedro Dr. SE,

Albuquerque, NM 87108, USA

\section{Evolution and Medical Education}

Medical students must learn an ever-increasing volume of information in medical school. Many worthy topics, including prevention, public health, clinical reasoning, ethics, health policy, communication skills, and professionalism, now compete with the traditional core biomedical sciences, such as biochemistry, genetics, and pathophysiology. It is no wonder then that any effort to introduce another science-evolutionary biology-into the medical curriculum is a difficult endeavor.

In a 2003 survey of North American medical school deans, $48 \%$ said understanding the concepts of evolution is important for physicians. However, not a single medical school taught evolutionary biology as a basic science, no medical school required evolution as a prerequisite for admission, only $16 \%$ had Ph.D. faculty in evolutionary biology, and schools devoted a median of only four hours of curricular time on core topics in evolution (Nesse and Schiffman 2003). Complicating matters further, one of ten medical students in Glasgow rejected the notion of long-term evolution on religious grounds (Downie 2004). Thus, more than 15 years after the publication of the seminal text, Why We Get Sick: The New Science of Darwinian Medicine (Nesse and Williams 1994), many physicians remain unaware of evolution's most relevant principles.

Evolutionary (Darwinian) medicine is the application of evolutionary principles, including natural selection, adaptation, phylogenetics, and evolutionary constraints, to understanding health and disease. In this paper, we argue that a working knowledge of evolution is well worth the time and effort by students of medicine. We review selected concepts in evolutionary medicine that 
we wish we had learned when we were in medical school. This missed educational opportunity would teach students to ask evolutionary "why" questions of diseases and develop skills to recognize evolutionary paradoxes and patterns in medicine. As we describe, evolutionary biology is an integrative science whose concepts can help students and professionals improve learning, teaching, practice, and research across the spectrum of biomedicine.

\section{Educational Implications}

When asked, students are intrigued by large "why" questions such as: Why do we age? Why do so many of us wear glasses? Why is there a menopause? Why must we sleep? Why do we still have an appendix? Why are autoimmune disorders becoming more prevalent? Most students hear these as questions of how the body works and are accustomed to detailed descriptions of pathophysiology. These proximate causes describe the immediate mechanisms underlying a disease and form the conceptual and cognitive framework for our models of learning, practice, and research. However, such bodily mechanisms tell only half of the story. To fully understand the complexities of these problems, we must ask questions at the ultimate, or evolutionary, level of causation (Harris and Malyango 2005). Taking an evolutionary lens to these "why" questions can bring novel and unexpected answers that draw on phylogenetic relationships, constraints, and selection. Understanding how human vulnerabilities to disease are caused by evolutionary tradeoffs and reflect natural selection and its limitations rather than faulty engineering offers learners a framework for making medical education more coherent (Nesse and Williams 1999). In our experience, medical students find evolutionary science intriguing and are eager to learn more but are disappointed with the lack of opportunities to study evolution.

Medical schools are complex institutions that are slow to change. Jack Colwill aptly wrote, "We educate tomorrow's physicians in today's system while maintaining yesterday's beliefs" (Colwell 2004). Curricular time is precious, and many valuable fields vie for larger roles in educating physicians. However, it has been argued that teaching evolutionary concepts such as selection, common ancestry, phylogenetics, and tree-thinking (Baum et al. 2005) provides an integrated, conceptual scaffold, a cognitive hat rack on which medical facts can be organized. Infusing the concepts of evolution into medical education can help students build the bridges and tunnels they need to connect and navigate what is otherwise an archipelago of basic and clinical sciences.

\section{Clinical Implications}

Physicians in training learn to identify illnesses by recognizing patterns of signs and symptoms. However, students often find it hard to conceptually distinguish host defenses (e.g., fever) from true pathological defects (e.g., seizures) in disease. For example, while fever was once viewed as pathological, current recommendations advocate against treating fever in children (Sullivan and Farrar 2011), correctly noting that "fever...is not the primary illness but is a physiologic mechanism that has beneficial effects in fighting infection." Fever is increasingly viewed as an adapted facultative response (Kluger et al. 1996).

Other host defenses include the capacity to respond to pain and anxiety, thus limiting exposure to danger. Nesse observed that aversive symptoms, such as anxiety and panic, seem to afflict many people out of proportion to any potential threat. $\mathrm{He}$ argues that natural selection has shaped defensive responses that are akin to a smoke detector: highly sensitive to potential fires, but prone to frequent false alarms (Nesse and Williams 1994). In this signal-detection metaphor, a low threshold for activation of the fight-or-flight response, though energetically costly during a false alarm (anxiety or panic attack), can prevent the far higher fitness cost of being killed by a predator or conspecific. What appears to be "over-expression" could instead be the outcome of optimal regulation of a defense trait. Frequent false alarms can be expected when (1) the cost of a defense is less than the cost of the danger, (2) threats are unpredictable across time and space, and (3) signals conveying danger are imperfect (Nesse 2001).

While the smoke detector principle does not imply that every patient's symptom is "optimal," it can inform how clinicians frame and discuss signs and symptoms with patients. When appropriate, a patient's cough might be contextualized as evidence of a healthy response rather than a symptom to be suppressed. In other instances, patients might benefit from attenuation of symptoms that are false alarms. A challenge, then, is deciding when a symptom is a false alarm. Allergic symptoms provide such a dilemma. While there is some support for the view that allergy provides an anti-toxin benefit (Profet 1991), severe allergy (anaphylaxis) is deadly, requiring immediate life-saving medical treatment. The paradox of deadly hypersensitivity reactions to innocuous triggers, such as peanuts and pollen, has led some researchers to speculate that a changed modern environment causes the immune system to misfire in allergic and related diseases (Strachan 1989; Bach 2002).

Over the last half-century, the incidence of many infectious diseases has decreased dramatically (e.g., measles, tuberculosis, rheumatic fever, and hepatitis A), while that for autoimmune-related disorders has reciprocally increased (e.g., multiple sclerosis, Crohn disease, asthma, 
and type I diabetes) (Bach 2002). These contrasting trends have been attributed to improved hygiene in developed nations (Bach 2002). The so-called hygiene hypothesis gained attention when Strachan identified an inverse relationship between family size and allergic diseases and suggested that childhood infections have a protective effect for allergy (Strachan 1989). Now termed the "old friends" hypothesis, it contends that increases in autoimmune inflammatory disorders in developed countries are partly attributable to decreasing exposure to microorganisms with which humans coevolved (Rook 2007). Research informed by the evolutionary principle of genetic-environmental mismatch (Nesse and Williams 1994) has led to increased understanding of the important immunoregulatory roles played by various helminths and other members of the human microbiome (the communities of microorganisms that inhabit human skin, gut, respiratory and genitourinary tracts). For instance, the presence of intestinal helminths is associated with decreased disease severity in multiple sclerosis (Correale and Farez 2011). Based on findings like these, prospective trials of helminthic therapy (ingestion of nematodes) are underway to treat multiple sclerosis (Benzel et al. 2011) and Crohn disease (Reddy and Fried 2009).

\section{Public Health Implications}

In the hospitals where we work, there are periodic campaigns to improve rates of hand washing by healthcare workers. A recent meta-analysis of 96 studies highlighted the persistent problem of proper hand washing, which occurs only $40 \%$ of the time when it is needed (Erasmus et al. 2010). Most physicians do not realize that their bad habits might be responsible for the evolution of virulent strains of bacteria in hospitals (Ewald 2004). Virulence describes the capacity of a parasite or pathogen to harm its host. Virulent host-pathogen relationships can evolve depending on the mode of transmission (Day 2002; Ewald 2004). Infections are often more virulent and more deadly when they are transmitted by an outside agent, such as a needle, a clinician's hands, or a mosquito (Ewald 2004). The protozoan that causes the deadliest form of malaria, Plasmodium falciparum, is transmitted best when its human host is incapacitated. In nearly killing its host, P. falciparum makes an infected human an easy target for a mosquito and thus is more easily transmitted (Paul et al. 2004). By contrast, infections like the common cold are transmitted by direct contact and thrive when their host remains active, which serves to bring the virus to the next susceptible victim. In hospitals, we healthcare workers behave much like mosquitoes, often unknowingly transmitting microbes on our hands and stethoscopes between hospitalized patients. The clustering of susceptible individuals also is ideal for the evolution of highly virulent organisms (Mennerat et al. 2010). One recent example is the emergence of a hypervirulent strain of Clostridium difficile that produces a newly identified toxin (binary toxin) in addition to the cytotoxins that allow the pathogen to invade intestinal epithelial cells. Between 2003 and 2005, epidemics of binary toxin producing $C$. difficile occurred in Canada, the United States, and Europe (Dawson et al. 2009). The rapid evolution of hypervirulence in $C$. difficile has doubled the number of infections since 2000 and tripled the mortality rate (Pepin et al. 2005; Viswanathan et al. 2010).

Ewald suggests that interventions that alter transmission can alter the evolution of virulence (Ewald 2004). For acute infectious diseases, interventions that selectively reduce the transmission from the sickest individuals will favor the evolution of less virulent pathogens. For chronic infectious diseases, interventions that reduce the frequency of transmission opportunities will favor pathogens that cause less damage during the chronic phase (Ewald 2004). Simple public health measures, like hand washing, will decrease the infectious inoculum, help prevent disease outbreaks, as well as promote the evolution of less virulent pathogens. Students do not need to understand evolution to appreciate the value of hand washing and sterile technique in reducing nosocomial infections. However, linking these clinical habits to biologic principles of natural selection of virulence may deepen the lesson and promote learning and performance.

\section{Research Implications}

Over the past decade, the National Institutes of Health (NIH) roadmap has sought to bridge the gaps among our research silos, which have impeded the translation of evidence from bench to bedside, from bedside to community, and from community to populations (Zerhouni 2003). In a complementary manner, evolutionary science compels researchers to go beyond questions of proximate causality and to explore how human health and disease evolved over a longer time horizon. A complete and integrated answer to research questions of causality in health and illness requires both proximate and evolutionary approaches.

Evolutionary principles can provide conceptual scaffolding to guide the research agenda and may accelerate the adoption of new therapies for patients and treatment guidelines for populations. Evolutionary biology can promote such a translational research paradigm by integrating research from various disciplines and suggesting new questions and hypotheses to test.

Testing evolutionary hypotheses is challenging and often requires interdisciplinary collaboration among basic and clinical scientists using novel methods. Much interest has 
focused on why evolution has left our bodies so vulnerable to disease despite natural selection (Nesse and Williams 1994). Research design for such questions is hard to get right. Answering the sort of questions posed by inquisitive students noted above presents challenges in defining the object of explanation precisely and specifying the type of explanation being sought. This approach requires consideration of all viable hypotheses and selecting the most appropriate methods to test the hypotheses (Nesse 2011).

Physicians are all too familiar with the vulnerabilities of the human body. The conventional view is that every part of the body is a potential source of cancer, degeneration, or failure, and every gene offers a chance for a genetic defect. In the medical centers where we work, students learn about genetic disorders with little to no discussion of evolution, even when mutations are far too prevalent to be simply sporadic (Harris and Meyer 2006). Genetic drift or bottleneck effects explain many common variant alleles, while balancing selection maintains others (processes that conserve genetic polymorphism, usually when heterozygotes for an allele enjoy greater reproductive fitness than do homozygotes) (Im et al. 2011).

The high prevalence of certain mutations can be a tip-off for a selective benefit, like the heterozygote advantage that protects sickle cell carriers from severe malaria (Allison 2004). Other common "defects" should also raise questions among students: "Why did natural selection fail to eliminate this gene or mechanism if it is harmful?" These queries can be applied to common genetic polymorphisms such as Factor V Leiden (a common source of deadly blood clots), apolipoprotein E4 (a variety that is associated with Alzheimer's disease), the breast cancer (BRCA-1) gene, not to mention the harmful biochemical pathways that lead to cardiovascular diseases and type II diabetes (Table 1). Students will want to know why these traits occur, when logic would suggest that they would face strong negative selection. The opposite condition is equally puzzling: protective traits, e.g., free radical scavengers and heat shock proteins, are often not expressed. These evolutionary paradoxes are everywhere in medicine. However, they are more apparent to those with an understanding of evolutionary biology. Each of these questions can generate multiple hypotheses, many suitable for testing by the next generation of clinician scientists.

\section{Summary}

In this brief overview, we have focused on evolutionary medicine concepts that are important for students and trainees. Students would do well to search the literature for evolutionary work relevant to their fields of interest. No obstetrician gynecologist should learn about preeclampsia and gestational diabetes without studying David Haig's work on genetic conflicts during pregnancy (Haig 1993). No gerontologist should consider the aging process without appreciating the declining power of selection and tradeoffs between reproduction and longevity (Kirkwood 1997). Every epidemiologist and infectious disease specialist should be able to engage in "tree-thinking" (Baum et al. 2005) and interpret the phylogenetic trees used to track the evolution of HIV (Woroby et al. 2008) and the emergence of North American West Nile virus (McMullen et al 2011). It is beyond the scope of this article to detail these and many other important concepts and applications of evolutionary biology in medicine, and we hope that students will be inspired to explore them further. A good place for students to start is the textbook Principles of Evolutionary Medicine (Gluckman et al. 2009) and the website The Evolution \& Medicine Review (http://evmedreview.com).

No less important than its practical implications, an evolutionary framework is a source of important medical insights that provide a sense of discovery about the human condition. Testing evolutionary hypotheses of disease moves us closer to understanding ourselves and the myriad ways in which our bodies fail us. We hope that medical students who learn to ask "why" questions will also gain the skills to understand and critically evaluate evolutionary

Table 1 Hypotheses for adaptation or balancing selection in human diseases

\begin{tabular}{|c|c|c|c|}
\hline Finding & Disease association & Potential benefit & Selected references \\
\hline Factor V Leiden & Thromboembolism & $\begin{array}{l}\text { Decreased peripartum bleeding } \\
\text { Survival benefit in sepsis }\end{array}$ & $\begin{array}{l}\text { Franchini and Mannucci 2008; } \\
\text { Lindqvist and Dahlback } 2008\end{array}$ \\
\hline Apo E & $\begin{array}{l}\text { Alzheimer's, } \\
\text { cardiovascular disease }\end{array}$ & $\begin{array}{l}\text { Anti-pathogen defense } \\
\text { Decreased diarrhea }\end{array}$ & $\begin{array}{l}\text { Finch and Stanford } 2004 \\
\text { Oria et al. } 2010\end{array}$ \\
\hline BRCA-1 & Breast cancer & $\begin{array}{l}\text { Unknown. Evidence } \\
\text { for positive selection } \\
\text { None. Evidence for founder effect }\end{array}$ & $\begin{array}{l}\text { O’Connell } 2010 \\
\text { Im et al. } 2011\end{array}$ \\
\hline $\begin{array}{l}\text { Pro-inflammatory pathways } \\
\text { involved in obesity }\end{array}$ & $\begin{array}{l}\text { Diabetes, } \\
\text { cardiovascular disease }\end{array}$ & $\begin{array}{l}\text { Enhanced innate immunity } \\
\text { Buffering energetic uncertainties }\end{array}$ & $\begin{array}{l}\text { Roth et al. } 2011 \\
\text { Kuzawa 1998; Wells } 2006\end{array}$ \\
\hline
\end{tabular}


hypotheses. We are confident that future students will devise innovative ways to test hypotheses of evolution in health and disease, work that will enrich the art and the science of medicine.

\section{References}

Allison AC. Two lessons from the interface of genetics and medicine. Genetics. 2004;166(4):1591-9.

Bach J. The effect of infections on susceptibility to autoimmune and allergic diseases. N Engl J Med. 2002;347(12):911-20.

Baum D, DeWitt S, Donavan S. The tree-thinking challenge. Science. 2005;310:979-80.

Benzel F, Erdur H, Kohler S, Frentsch M, Thiel A, Harms L, Wandinger KP, Rosche B. J Helminthol. 2011;1-9 (in press).

Colwell J. Primary care medicine and the education of generalist physicians. San Francisco: Jossey-Bass; 2004.

Correale J, Farez MF. The impact of parasite infections on the course of multiple sclerosis. J Immunol. 2011;233:6-11.

Dawson LF, Valiente E, Wren BW. Clostridium difficile - a continually evolving and problematic pathogen. Infect Genet Evol. 2009;9 (6):1410-7.

Day T. The evolution of virulence in vector-borne and directly transmitted parasites. Theor Popul Biol. 2002;62(2):199-213.

Downie JR. Evolution in health and disease: the role of evolution in biology in the medical curriculum. Biosci Educ Electron J. 2004;4:1-18.

Erasmus V, Daha TJ, Brug H, Richardus JH, Behrendt MD, Vos MC, et al. Systematic review of studies on compliance with hand hygiene guidelines in hospital care. Infect Control Hosp Epidemiol. 2010;31(3):283-94.

Ewald PW. Evolution of virulence. Infect Dis Clin North Am. 2004;18 (1): $1-15$.

Finch CE, Stanford CB. Meat-adaptive genes and the evolution of slower aging in humans. Q Rev Biol. 2004;79(1):3-50.

Franchini M, Mannucci PM. The hemostatic balance revisited through the lessons of mankind evolution. Intern Emerg Med. 2008;3 (1):3-8.

Gluckman P, Beedle A, Hanson M. Principles of evolutionary medicine. New York: Oxford University Press; 2009.

Haig D. Genetic conflicts in human-pregnancy. Q Rev Biol. 1993;68 (4):495-532.

Harris EE, Malyango AA. Evolutionary explanations in medical and health profession courses: are you answering your students' "why" questions? BMC Med Educ. 2005;5(1):16.

Harris EE, Meyer D. The molecular signature of selection underlying human adaptations. Am J Phys Anthropol Suppl. 2006;43:89130.

Im KM, Kirchhoff T, Wang X, Green T, Chow CY, Vijai J, Korn J, Gaudet MM, Fredericksen Z, Shane Pankratz V, Guiducci C, Crenshaw A, McGuffog L, Kartsonaki C, Morrison J, Healey S, Sinilnikova OM, Mai PL, Greene MH, Piedmonte M, Rubinstein WS, HEBON, Hogervorst FB, Rookus MA, Collee JM, Hoogerbrugge N, van Asperen CJ, Meijers-Heijboer HE, Van Roozendaal CE, Caldes T, Perez-Segura P, Jakubowska A, Lubinski J, Huzarski T, Blecharz P, Nevanlinna H, Aittomaki K, Lazaro C, Blanco I, Barkardottir RB, Montagna M, D'Andrea E, kConFab, Devilee P, Olopade OI, Neuhausen SL, Peissel B, Bonanni B, Peterlongo P, Singer CF, Rennert G, Lejbkowicz F, Andrulis IL, Glendon G, Ozcelik H, Ontario Cancer Genetics Network, Toland AE, Caligo MA, SWEBRCA, Beattie MS, Chan S, UKFOCR, Domchek SM, Nathanson KL, Rebbeck TR, Phelan C, Narod S, John EM, Hopper JL, Buys SS, Daly MB, Southey MC, Terry MB, Tung N, Hansen TV, Osorio
A, Benitez J, Duran M, Weitzel JN, Garber J, Hamann U, EMBRACE, Peock S, Cook M, Oliver CT, Frost D, Platte R, Evans DG, Eeles R, Izatt L, Paterson J, Brewer C, Hodgson S, Morrison PJ, Porteous M, Walker L, Rogers MT, Side LE, Godwin AK, Schmutzler RK, Wappenschmidt B, Laitman Y, Meindl A, Deissler H, Varon-Mateeva R, Preisler-Adams S, Kast K, Venat-Bouvet L, Stoppa-Lyonnet D, Chenevix-Trench G, Easton DF, Klein RJ, Daly MJ, Friedman E, Dean M, Clark AG, Altshuler DM, Antoniou AC, Couch FJ, Offit K, Gold B. Haplotype structure in Ashkenazi Jewish BRCA1 and BRCA2 mutation carriers. Hum Genet. 2011; May 20 Epub ahead of print.

Kirkwood TB. The origins of human ageing. Philos Trans R Soc Lond B Biol Sci. 1997;352(1363):1765-72.

Kluger MJ, Kozak W, Conn C, Leon L, Soszynski D. The adaptive value of fever. Infect Dis Clin North Am. 1996;10(1):1-20.

Kuzawa CW. Adipose tissue in human infancy and childhood: an evolutionary perspective. Am J Phys Anthropol Suppl. 1998;27:177-209.

Lindqvist PG, Dahlback B. Carriership of Factor V Leiden and evolutionary selection advantage. Curr Med Chem. 2008;15 (15):1541-4

McMullen AR, May FJ, Li L, Guzman H, Bueno Jr R, Dennett JA, et al. Evolution of new genotype of West Nile virus in North America. Emerg Infect Dis. 2011;17(5):785-93.

Mennerat A, Nilsen F, Ebert D, Skorping A. Intensive farming: evolutionary implications for parasites and pathogens. Evol Biol. 2010;37(23):59-67.

Nesse RM. The smoke detector principle. Natural selection and the regulation of defensive responses. Ann N Y Acad Sci. 2001;935:75-85.

Nesse RM. Ten questions for evolutionary studies of disease vulnerability. Evol Appl. 2011;4(2):264-77.

Nesse RM, Schiffman JD. Evolutionary biology in the medical school curriculum. Bioscience. 2003;53(6):585-7.

Nesse RM, Williams GC. Why we get sick. New York: The new science of Darwinian medicine. Times Books; 1994.

Nesse RM, Williams GC. On Darwinian medicine. Lfe Sci Res. 1999;3:1-17.

O'Connell MJ. Selection and the cell cycle: positive Darwinian selection in a well-known DNA damage response pathway. J Mol Evol. 2010;71(5-6):444-57.

Oria RB, Patrick PD, Oria MO, Lorntz B, Thompson MR, Azevedo OG, et al. ApoE polymorphisms and diarrheal outcomes in Brazilian shanty town children. Braz J Med Biol Res. 2010;43(3):249-56.

Paul REL, Lafond T, Muller-Graf CDM, Nithiuthai S, Brey PT, Koella JC. Experimental evaluation of the relationship between lethal or non-lethal virulence and transmission success in malaria parasite infections. BMC Evol Biol. 2004;4:30.

Pepin J, Valiquette L, Cossette B. Mortality attributable to nosocomial Clostridium difficile-associated disease during an epidemic caused by a hypervirulent strain in Quebec. CMAJ. 2005;173(9):1037-42.

Profet M. The function of allergy: immunological defense against toxins. Q Rev Biol. 1991;66(1):23-62.

Reddy A, Fried B. An update on the use of helminths to treat Crohn's and other autoimmune diseases. Parasitol Res. 2009;104(2):217-21.

Rook G. The hygiene hypothesis and the increasing prevalence of chronic inflammatory disorders. Trans R Soc Trop Med Hyg. 2007;101 (11):1072-74.

Roth J, Szulc AL, Danoff A. Energy, evolution, and human diseases: an overview. Am J Clin Nutr. 2011;93(4):875S-83.

Strachan DP. Hay fever, hygiene, and household size. BMJ. 1989;299 (6710):1259-60.

Sullivan JE, Farrar H. Fever and antipyretic use in children. Pediatrics. 2011;127(3):580-7.

Viswanathan VK, Mallozzi MJ, Vedantam G. Clostridium difficile infection: an overview of the disease and its pathogenesis, 
epidemiology and interventions. Gut Microbes. 2010;1(4):23442.

Wells JC. The evolution of human fatness and susceptibility to obesity: an ethological approach. Biol Rev Camb Philos Soc. 2006;81(2):183-205.
Woroby M, Gemmel M, Teuwen DE, Haselkorn T, Kunstman K, Bunce M, et al. Direct evidence of extensive diversity of HIV-1 in Kinshasa by 1960. Nature. 2008;455(7213):661-4.

Zerhouni E. Medicine. The NIH roadmap. Science. 2003;302 (5062):63-72. 